\title{
The Effect of Human Resources Input in Enterprise Management in Taiwan
}

\author{
Chien-Ming Huang ${ }^{1}$, Hsin-Mei Su${ }^{2} \&$ Tung-Kuan $\operatorname{Lin}^{3}$ \\ ${ }^{1}$ Department of Banking and Finance, Tamkang University, Taiwan \\ ${ }^{2}$ Department of Planning, The Institute of Energy Economics, CPC Corporation, Taiwan \\ ${ }^{3}$ Department of Banking and Finance, Tamkang University, Taiwan \\ Correspondence: Tung-Kuan Lin, Department of Banking and Finance, Tamkang University, No.151, Yingzhuan \\ Rd., Tamsui Dist., New Taipei City 251, Taiwan (R.O.C.). Tel: 886-2-2621-5656. E-mail: \\ kerry1461@gmail.com
}

Received: April 20, 2015

Accepted: July 17, 2015

Online Published: July 25, 2015

doi:10.5539/ijef.v7n8p123

URL: http://dx.doi.org/10.5539/ijef.v7n8p123

\begin{abstract}
This paper adopts the multiple regimes model to analyze the relations among intangible assets, firm growth and enterprise risk in Taiwan-listed companies. In contrast to previous studies, this paper calculates an indicator of human capital's excess value to examine whether the human resources allocation difference influences enterprise risk in accordance with Pantzalis and Park (2009). Our results show that there is a significant asymmetric non-linear relation between human resources and enterprise risk. We find that size and the $\mathrm{M} / \mathrm{B}$ ratio exhibit a multiple threshold effect with enterprise risk. When the firm is large and has a high $\mathrm{M} / \mathrm{B}$ ratio, there is a significant negative relationship between human resources and enterprise risk; however, this link does not occur with small firms. Finally, the enterprise risk is positively associated with research and development expenses. In summary, the phenomenon may be attributed to the efficiency of innovation.
\end{abstract}

Keywords: multiple regimes model, firm growth, threshold effect, human resources, enterprise risk

\section{Introduction}

Taiwan was one of four Asian tigers the world never imagined. Its rapid economic growth, which has been called an economic miracle, has been an important area in economic research. Over the past 20 years, Taiwan metamorphosed from an emerging economy to a mature economy and has had a sharp slowdown in economic growth. Most enterprises have been in a quandary regarding whether to remain in Taiwan or move to China, to reduce labor costs and avoid other unnecessary expenses. Regardless, this decision has ignored the weakness of Taiwanese firms. Over $90 \%$ of Taiwanese firms are small and medium enterprises, the majority of which benefited from cheap labor and OEM (Original Equipment Manufacturing) products that were no longer competitive. Liu and Shyu (2004) show that OEM (Original Equipment Manufacturing) is a transitional period; the final purpose is to technologically develop unique patents. Coad and Rao (2010) specifically noted the importance of research and development (R\&D) investment to a company. By contrast, Taiwan's competitor, South Korea, helped its enterprises develop private brands and encouraged the firms to recruit professionals from abroad. In our view, the most serious problem in Taiwanese firms is a complete lack of awareness regarding the emergence of the knowledge-based economy. An excessive number of firms are expending enormous energy to simply reduce costs such as R\&D expenditures and personnel costs. Personnel costs are part of human resources management; thus, a reduction may adversely affect company performance. According to previous studies, human resources is the key factor for company growth (Huselid et al., 1997; Lepak \& Snell, 2002; Batt, 2000).

Human resources issues have been extensively researched in recent years; human resources is generally believed to improve firm performance and productivity (Huselid, 2000; Bosma et al., 2002; Youndt \& Snell, 2004). Human capital is part of human resources but is slightly different. Coff (2002) notes that combining people's knowledge, skills and experience can create more firm value. Thus, human capital is useful to efficiency and decisions and in decreasing imitability. Many past researchers agree there is a significant linkage between human capital and firm performance (Pantzalis \& Park, 2009; Hayton, 2003; Carpenter et al., 2001; Ballot et al., 2001; Hitt et al., 2001). These researchers imply that firms with more human capital will experience firm growth; 
nevertheless, we are certain that excessive investment in human capital will have exactly the reverse effect. To test the relation between human capital and firm growth, the market value of equity to book value of equity (M/B ratio), which is the best proxy of firm performance and firm growth (Baker \& Wurgler, 2002), we group high growth (high $\mathrm{M} / \mathrm{B}$ ratio) and low growth (low $\mathrm{M} / \mathrm{B}$ ratio) companies to analyze the information further.

The finance literature often discusses company risk factors, such as cash flow, credit rating, and financial decisions. To our knowledge, a growing body of empirical research examines enterprise risk and firm growth (McShane et al., 2011; Kini \& Williams, 2012; Penman \& Reggiani, 2013; Singla et al., 2014). These researchers argue how firm growth increases risk. An important insight from certain literature is that enterprise risk appears to be influenced by over-expansion. Companies experiencing competition and limited cash flow may make erroneous decisions and increase risk. Acharya et al. (2012), and Palazzo (2012) show that increased cash holdings should be safer; riskier firms should therefore attempt to increase cash reserves.

Consequently, there is a connection between human resources and firm performance. Hitt et al. (2001) and Hayton (2003) indicated that human resources inputs do not positively affect firm performance, depending on a firm's situation or size. If more human resources inputs cannot absolutely increase firm performance, the relative uncertainty increases. Many papers have discussed how to improve firm performance using risk management. Additionally, enterprises may hire chief risk officers to manage risk-related activities. However, that analyzes the relation between human resources and risk is lacking. We start with the premise of human resources as a positive influence, and we further explore whether risk increases.

The major contributions of this paper are summarized as follows. First, the objective of this paper is to analyze the relations between human resources and risk. Previous studies have focused on the link between firm growth and risk; these studies generally omit relevant human resources factors (Mcshane et al., 2011; Soininen et al., 2012; Singla et al., 2013; Sadorsky, 2012; Penman \& Reggiani, 2013; Kini \& Williams, 2012). Human resources is defined as an intangible asset to create firm value. In contrast, certain literature argued that human resources also could increase enterprise costs; these extra costs could increase enterprise risk. Second, our results show that there is a significant asymmetric non-linear relation between human resources and enterprise risk. We find that size and $\mathrm{M} / \mathrm{B}$ ratio exhibit a threshold effect with enterprise risk: when the firm is large and has a high $\mathrm{M} / \mathrm{B}$ ratio, there is a significant linkage between human resources and enterprise risk; however, this does not occur with small firms. The asymmetry implies the existence of two or more switching regimes. Moreover, most literature adopts traditional methods to classify groups, for example, the mean, median, and mode. Hansen (1999) developed an alternative theory known as the threshold variable of modification; this variable is necessary to avoid deficiencies caused by subjective measurement. Third, Pantzalis and Park (2009) posit that a new human resources indicator is a mispricing measurement. Hirshleifer (2001) suggested that security valuations involve all firm factors; however, the information regarding human capital is sparse, more easily causing mispricing. Lev (2001) notes that offering intangibles in reports may reduce stock return volatility. Therefore, we select Pantzalis and Park's (2009) quantity indicator of excess value of human capital (EVHC) to explore the effect of human resources inputs in enterprise risk management. Finally, the ordinary least squares (OLS) method is not adequate to test whether these unmeasured individual characteristics have so-called heterogeneity. Reviewing past literature, the researchers constructed a panel model to control endogeneity and unobservable heterogeneity across firms. Consequently, this paper combines panel data and the multiple regimes model proposed by Hansen (2000) to analyze the relations among intangible assets, firm growth and enterprise risk in Taiwan-listed companies.

The remainder of this paper is organized as follows. Section 2 addresses previous research and outlines the issues with intangible assets, human resources, firm performace and enterprise risk. Section 3 defines the variables and the methodology. Section 4 discusses the data and provides summary statistics. In section 5, we provide our empirical results. Section 6 provides a summary and conclusions.

\section{Review of Literature}

For top management or stockholders, the value of intangible assets is difficult to measure precisely. Most firms prefer to invest in items characterized by quick returns and low costs. However, relevant studies of intangible assets involve many related issues that are critical to enterprise management. It is natural for a company to change operating methods for profitability; these companies should choose to invest more heavily in intangible assets (Lu \& Beamish, 2004). Delios and Beamish (2001) argue that intangible assets directly influence the probability of a company's survival. Harris and Moffat (2013) consider that intangible assets are a factor for managing a company that drives firm value. Intangible assets are very important; these include R\&D expenditures, goodwill, brand, and human resources. 
In the 21 st century, as the Taiwan domestic market was saturated, firms expected products to be exported overseas. With rapid market globalization, firm managements are encountering different situations and challenges, such as low priced products or high quality products. Management cannot rely on the past empirical rule to reduce personnel costs or on intangible assets to maintain profits. Empirical research refers to a knowledge-base as the core competence of enterprises. Through creating competitive advantages and increasing the book value of intangible assets denoted as intellectual capital, there is more evidence to support positive relations with firm performance (Mavridis, 2004; Youndt \& Snell, 2004; Goh, 2005; Zeghal \& Maaloul, 2010; Cheng et al., 2010). Intellectual capital is based employees' knowledge, expertise, and skills and is used to create trademarks or patents. We posit that an excellent company needs not only quality capital management but also professionals. Company employees embody the valuable human capital that should produce a higher return (Sherer, 1995). Carpenter et al. (2001) find firms that develop human capital will benefit through multinational firm performance. Skaggs and Youndt (2004) discuss combining strategic and human capital, and examine how the interaction impacts organization performance. Gimeno et al. (1997) note that, although companies with equal conditions do not all survive, human capital will increase the survival rate of underperforming firms. From the above reviews, many researchers agree that human capital has a positive effect on firm performance. Relating to firm performance, Pantzalis and Park (2009) attempt to use stock returns to measure firm performance. Batt (2000) examined the relation between human capital and sales growth. Shrader and Siegal (2007) indicated that sales growth is applicable to company performance. Baker and Wurgler (2002) used the M/B ratio, which is the best proxy of firm performance and firm growth. In our study, we also agree with the selection of the M/B ratio to find the potential for future profitable investment. For human capital measurement, we adopt and modify the excess value of human capital (EVHC) indicator to examine the human capital effect on firm growth.

The definition of corporate risk is that the outcome of business activities is uncertain and will have a negative impact on company management. Corporate risk in the finance area, defined as the uncertainty of a return on assets; the standard deviation of the return on total investment usually is selected for risk measurement. Lakonishok and Shapiro (1986) adopted residual standard deviation to measure risk. Estrada (2002) used the semi-standard deviation method to investigate the risk of investment decisions. Duffie and Pan (1997) assume that $\mathrm{VaR}$ is the maximum possible loss in given confined levels and periods; the VaR method is an effective method of risk measurement if used with care. In the past, risk measurement studies were abundant. For empirical evidence regarding risk and firm performance, most literature do not hold an identical view. Some texts have analyzed the relations among each of the following aspects: cash flow, credit default, and capital structure. Psillaki et al. (2010) evaluate credit default and firm performance. Psillaki based his research on the industry's best practices to investigate whether productive inefficiency is a business failure predictor. Pagach and Warr (2010) find that well-managed risk will reduce stock price volatility and decrease the market-to-book ratio. Quon et al. (2012) focused on firm performance during the financial crisis; risk management information did not affect business performance. Kang et al. (2011) considered that to diversify business risk is to embark on different areas of a commercial business, adopting a geographic diversification strategy to decrease both risk and performance. Johnson et al. (2000) discussed how corporate governance affect firm performance and how risk, cash holdings and enterprise risk are closely related. Conversely, much new literature shows that firm growth is more applicable to firm performance (Hoyt \& Liebenberg, 2011; Mcshane et al., 2011; Kini \& Williams, 2012). Our paper thus adds to the existing literature's concept on the M/B ratio by examining enterprise risk.

Consistent with past research, there is a concurrence of opinion on each relation between enterprise risk, human resources, and firm performance. There is no acceptable argument regarding how human resources inputs likely increase firm performance, and whether increased firm growth likely increases enterprise risk. Guest (2010) reviews a series of relevant research in human resources development; however, he remains unable to answer the core question between human resources and firm performance. Moreover, previous evidence shows that appropriate human resources investment is related to firm performance, and steady firm growth also controls firm risk. Hitt et al. (2001) hold a different opinion. These researchers believe that more human capital increases firm performance, and this has a $\mathrm{U}$-shaped effect. These researchers ignore the likelihood that firm performance is partially offset by excessive human resources inputs. Hayton (2003) particularly discusses the entrepreneurial ability of small and medium size enterprises (SMEs); the characteristics of SMEs are innovation, risk taking, and opportunity exploitation. SMEs should strive to develop access to human capital that drive a firm's rapid acquisition and achievement of new technology and a high market share. There is a strong relation between firm performance and human resources for SMEs. Accordingly, SMEs or firms with high growth characteristics should focus on human capital development. For maximum effectiveness, high growth and low growth companies encounter different situations in which to make human resources decisions or control cash flow. High growth companies must invest more capital in human resources to maintain and obtain competitive advantages in 
the future. By contrast, low growth companies have limited capital and cash holdings to control and less investment opportunities for expenditures on intangible assets. Past studies have not discussed how human capital inputs positively or negatively affect firm performance. This is consistent with the cash flow factor, which affects a firm's cash holdings and determines whether cash holdings are related to company performance and value (Brush et al., 2000; Haw et al., 2001; Brown et al., 2009; Naoki, 2012; Kalcheva \& Lins, 2015). Regarding this cash flow factor, excessive expenditures on human resources may have a negative effect and increase enterprise risk. The financial issues ignore the premise that strategic investment in human resources should depend on firm growth; an inappropriate strategy results in additional risk through reduction of a firm's growth. Human resources, firm performance, and enterprise risk are closely related; however, there are no relevant papers to examine. In our study, we suppose human resources relate to firm growth, and firm growth affects enterprise risk. To find the correlation among human resources, firm performance and enterprise risk, we will examine each separately.

\section{Methodology}

\subsection{Variable Definition}

\subsubsection{Dependent Variable}

Enterprise is the dependent variable. In accordance with Vassalou and Xing's (2004) pattern, we adopt a KMV model to estimate the default risk of firms. This model calculates the expected default frequency based on a firm's capital structure, the volatility of its asset returns, and the firm's current asset value. According to Oderda et al. (2003), the time-varying characteristics and forecasting ability of the KMV model is superior to other models and is best applied to the valuation of default risk in publicly traded companies. To estimate the expected default frequency (EDF), the estimation procedure is set as follows:

$$
d V_{A}^{T} / V_{A}^{T}=u d T+\sigma_{A} d Z_{T}
$$

Where $V_{A}^{T}$ is the total market value of assets for the firm at time $T ; u$ is the expected rate of return; and $\sigma_{A}$ is the volatility of asset returns. The option-pricing model is

$$
\begin{gathered}
V_{E}=V_{A} N\left(d_{1}\right)-X e^{-r_{f} T} N\left(d_{2}\right) \\
d_{1}=\left\{\ln \left(V_{A} / X\right)+\left(r_{f}+\sigma_{A} / 2\right) T\right\} / \sigma_{A} \sqrt{T}, d_{2}=d_{1}-\sigma_{A} \sqrt{T} \\
\sigma_{E}=\left(V_{A} / V_{E}\right) N\left(d_{1}\right) \sigma_{A}
\end{gathered}
$$

Where $V_{A}$ is the market value of assets, $V_{E}$ is the equity market value, $\sigma_{E}$ denotes the volatility of equity returns, $X$ is the book value of total debt, $T$ is the time to maturity of debt, $r_{f}$ is the one year risk free rate, $N\left(d_{1}\right)$ indicates the hedging ratio with a cumulative probability density function, and $N\left(d_{2}\right)$ represents the probability that the market value of the assets are greater than the liability at maturity $T$, which is a cumulative density probability function.

Given the original value of $X, r_{f}, \mu, T, \sigma_{E}$ and $V_{E}$, the implied market value and volatility of assets, $V_{A}$ and $\sigma_{A}$, can be calculated from Equations (2) and (4). Therefore, we calculate the book value of long-term debt and half of the short-term liabilities for each company to represent the strike price of an option $X$. Because Taiwan does not issue short-term government bonds, the one-year fixed-term deposit interest rate of Taiwanese banks and the return on asset are used as proxies for the risk-free rate $\left(r_{f}\right)$ and drift $(\mu)$. The estimated window $(T)$ is set to one year.

To investigate whether risk has a significant association with firm performance and human resources, we estimate EDF regressions using EDF (expected default frequency value) as the dependent variable, EVHC (excess value of human capital), MB (ratio of market value to book value of equity), LD (long-term debt divided by total asset), SIZE (natural logarithm of total assets), RADR (R\&D expenditures divided by total asset) and OCFR (operation cash flow divided by total asset) as independent variables. The EDF equation is:

$$
E D F_{i, t}=\alpha_{0}+\beta_{1} E V H C_{i, t}+\beta_{2} M B_{i, t}+\beta_{3} L D_{i, t}+\beta_{4} R A D R_{i, t}+\beta_{5} S I Z E_{i, t}+\beta_{6} O C F R_{i, t}+\varepsilon_{i, t}
$$

where $E D F_{i, t}$ is the expected default frequency value, $E V H C_{i, t}$ is the excess value of human resources for firm 
$i$ in year $t$, and $\varepsilon_{i, t}$ is the error item for firm $i$ in year $t$.

\subsubsection{Independent Variable}

Human resources is the independent variable. To represent human resources development, we act in accordance with Pantzalis and Park (2009) and select the excess value of human capital (EVHC). We compute the industry-median value for the ratio of market value of common equity to total number of employees. Next, we multiply the industry median EV by the firm's number of employees to obtain an imputed market value of human capital. Finally, the excess value of human capital of firm $i$ in year $t$ is then defined as the natural logarithm of the ratio of the firms' market value of common equity per employee to the industry's median value of market value of common equity per employee and is defined as follows:

$$
E V H C_{i, t}=\ln \left[(V / E M P)_{i, t} /(V / E M P)_{m, t}\right]
$$

Where $V_{i, t}$ and $V_{m, t}$ are the market value of common equity and the industry's mean value of market of common equity, respectively. $E M P_{i, t}$ and $E M P_{m, t}$ are the products of the number of employees of firm $i$ in year $t$ and the product of the number of employees of the industry median value of firm $i$ in year $t$.

\subsubsection{Contol Variable}

In this section, we will describe control variables for controlling the effect of a firm's characteristics. These control variables include the M/B ratio, $R \& D$ expenditures, Firm size, Firm leverage and Operating cash flow.

M/B Ratio (M/B): The M/B ratio represents the future growth opportunity (Baker \& Wurgler, 2002). It is proposed that higher growth opportunity is related to high return and low risk. We calculated the M/B ratio as stock price times the total number outstanding shares (market value) divided by the book value of equity.

Firm Leverage (LD): Companies often borrow capital to invest in business operations. Borrowed funds also have a tax shield via the high leverage as an expense deduction. Compared with a less leveraged company, higher debt may create a potential liquidity problem. Increasing excess debt likely leads to default risk (Vassalou \& Xing, 2004). Firm leverage is defined as long-term debt divided by total assets.

R\&D Expenditure (RADR): To analyze the effect of intangible assets on firm performance, we attempt to use $R \& D$ expenditures as one of the intangible variables. $R \& D$ is defined as a firm's capital inputs to develop technology or new products, or to survey customers' for opinions regarding product improvement. R\&D intensity usually is considered firm competition because new products and techniques affect firm performance and risk (Bloom \& Reene, 2002; Tubbs, 2007; Coad \& Rao, 2010). This intensity is calculated as research and development expenditures divided by total assets.

Firm Size (SIZE): In general, large firms own more resources overall than small firms. We are concerned that large firms have a stronger human resources effect regardless. In addition, factoring in firm size will enable a differential price rating that reflects the different degrees of risk taken, by firm size. Firm size and risk have a close relation (Podobnik et al., 2009). Firm size is a natural logarithm of total assets.

Operating Cash Flow (CFR): Cash flow and cash holdings are important parameters of enterprise risk. Enterprise risk should decrease closely with cash flow, based on past empirical evidence and theory. Operating cash flow represents the cash generated by a firm's normal business operation. Attar et al. (2008) used the variable to analyze bankrupt firms. Operating cash flow does include earnings before interest and taxes plus depreciation minus taxes, then divided by total asset.

\subsection{Empirical Method}

\subsubsection{Estimation}

This study focuses on examining the relation among human resources, firm growth and enterprise risk. The empirical model adopts the multiple regimes model, proposed by Hansen (2000), to investigate our proposed hypothesis. The estimation procedure is as follows:

$$
y_{i, t}=\theta^{\prime} x_{i}+\delta_{n}^{\prime} x_{i}(\gamma)+e_{i}, d_{i}(\gamma)=\left\{q_{i} \leq \gamma\right\}
$$

The observed sample can be expressed as $\left\{y_{i}, x_{i}, q_{i}\right\}_{i=1}^{n}$, where $y_{i}$ is $E D F_{i, t}$ measured by enterprise risk, $q_{i}$ are real-valued and $x_{i}$ is an m-vector, including $E V H C_{i, t}, L D_{i, t}, R A D R_{i, t}, O C F R_{i, t}$. The threshold variable $q_{i}$ may be an element of $x_{i}$ including $\operatorname{SIZE}_{i, t}, M B_{i, t}$ and is assumed to have a continuous distribution. This 
model allows the regression parameters to differ depending on the value of $q_{i}$. In addition, the $\{\cdot\}$ represents the indicator function and set $x_{i}(\gamma)=x d_{i}(\gamma)$. Equation (8) allows all 8 of the regression parameters to switch between the regimes; however, this is not essential to the analysis. The results generalize to the case where only a subset of parameters switch between regimes and to the case where certain regressors only enter into one of the two regimes. In matrix notation, we define the $n \times 1$ vectors $y$ and $e$ by stacking the variables $y_{i}$ and $e_{i}$, and define the $n \times m$ matrices $x$ and $x_{r}$ by stacking the vectors $x_{i}^{\prime}$ and $x_{i}(\gamma)^{\prime}$. This can be written as:

$$
Y=X \theta+X_{r} \delta_{n}+e
$$

The regression parameters are $\left(\theta, \delta_{n}, \gamma\right)$, and the natural estimator is least squares (LS). Let

$$
S_{n}\left(\theta, \delta_{n}, \gamma=\left(Y-X \theta-X_{r}^{\prime} \delta\right)(Y-X \theta-X\right.
$$

Be the sum of squared error function. Then, by definition, the LS estimators $\hat{\theta}, \hat{\delta}_{n}, \hat{\gamma}$ jointly minimize (9). Note that the LS estimator is also the MLE when $e_{i}$ is iid $N\left(0, \sigma^{2}\right)$. Conditional on $\gamma,(9)$ is linear in $\theta$ and $\delta_{n}$, yielding the conditional OLS estimators $\hat{\theta}(\gamma)$ and $\hat{\delta}(\gamma)$ by regression of $Y$ on $X_{\gamma}^{*}=\left[\begin{array}{ll}X & X_{\gamma}\end{array}\right]$. The concentrated sum of squared errors function is:

$$
S_{n}(\gamma)=S_{n}(\hat{\theta}(\gamma), \hat{\delta}(\gamma), \gamma)=Y^{\prime} Y-Y^{\prime} X_{r}^{*}\left(X_{r}^{*} X_{r}^{*}\right)^{-1} X_{r}^{* \prime} Y
$$

And $\hat{\gamma}$ is the value that minimizes $S_{n}(\gamma)$. Because $S_{n}(\gamma)$ takes on less than $\mathrm{n}$ distinct values, $\hat{\gamma}$ can be defined uniquely as

$$
\hat{\gamma}=\underset{\gamma \in \Gamma_{n}}{\arg \min } S_{n}(\gamma)
$$

Where $\Gamma_{n}=\Gamma \cap\left\{q_{1}, \cdots, q_{n}\right\}$, which requires less than $\mathrm{n}$ function evaluations. The slope estimates can be computed via $\hat{\theta}=\hat{\theta}(\hat{\gamma})$. If $\mathrm{n}$ is very large, $\Gamma$ can be approximated by a grid. For $N<n$, let $q_{(j)}$ denote the $(\mathrm{j} / \mathrm{N})$ th quantile of the sample $\left\{q_{1}, \cdots, q_{n}\right\}$, and let $\Gamma_{n}=\Gamma \cap\left\{q_{(1)}, \cdots, q_{(n)}\right\}$. Then, $\hat{\gamma}=\arg \min S_{n}(\gamma)$ is a suitable approximation to $\hat{\gamma}$, which requires $\mathrm{N}$ function evaluations. Therefore, in the leading case of conditional homoscedasticity (Note 1).

$$
E\left(e_{i}^{2} \mid q_{i}\right)
$$

The distribution function for $\mathrm{T}$ is known. (Refer to Bhattacharya and Brockwell, 1976). Let $\Phi(x)$ denote the cumulative standard normal distribution function. Then, for $x \geq 0$,

$$
P(T \leq x)=1+\sqrt{\frac{x}{2 \pi}} \exp \left(-\frac{x}{8}\right)+\frac{3}{2} \exp (x) \Phi\left(-\frac{3 \sqrt{x}}{2}\right)-\left(-\frac{x+5}{2}\right) \Phi\left(-\frac{\sqrt{x}}{2}\right)
$$

And for $x<0, P(T \leq X)=1-P(T \leq x)$.

\subsubsection{Likelihood Ratio Test}

To test the hypothesis $H_{0}: \gamma=\gamma_{0}$, a standard approach is to use the likelihood ratio statistic under the auxiliary assumption that $e_{i}$ is iid $N\left(0, \sigma^{2}\right)$. Let

$$
L R_{n}(\gamma)=n \times\left(S_{n}(\gamma)-S_{n}(\hat{\gamma})\right) / S_{n}(\hat{\gamma})
$$

The likelihood ratio test of $H_{0}$ rejects large values of $L R_{n}\left(\gamma_{0}\right)$ and provides the large sample distribution of the likelihood ratio test for hypothesis on $\gamma$. The asymptotic distribution is nonstandard, but free of nuisance parameters under (14). Because the distribution function is available in a simple closed form, it is easy to generate $\mathrm{p}$-values for observed test statistics, as follows

$$
P_{n}=1-\left(1-\exp \left(-0.5 L R_{n}\left(\gamma_{0}\right)^{2}\right)\right)^{2}
$$

Which is the asymptotic p-value for the likelihood ratio test. Critical values can be calculated by direct inversion of the distribution function. The test of $H_{0}: \gamma=\gamma_{0}$ will be rejected at the asymptotic level of $\alpha$, if it exceeds 
$c_{\xi}(1-\alpha)$, where $c_{\xi}(z)=-2 \ln (1-\sqrt{z})$. The 10 percent, 5 percent, and 1 percent critical values are 5.94, 7.35 and 10.59 , respectively.

\subsubsection{Threshold Estimate and Slope Parameters}

To form confidence for parameter $\gamma$, although the method commonly adopts the Wald or $\mathrm{t}$ statistics, Dufour (1997) argues that Wald statistics have particularly poorly-behaved sampling distributions when the parameter has a region where identification fails. These concerns have encouraged us to explore the construction of confidence regions based on the likelihood ratio statistic $L R_{n}(\gamma)$. First, let $\mathrm{C}$ denote the desired asymptotic confidence level, and let $c=c_{\xi}(c)$ be the $\mathrm{C}$-level critical value for $\xi$. Set

$$
\hat{\Gamma}=\left\{\gamma: L R_{n}(\gamma) \leq c\right\}
$$

Thus $\hat{\Gamma}$ is an asymptotic C-level confidence region for $\gamma$. If the homoscedasticity condition (9) does not hold, we can define a scaled likelihood ratio statistic:

$$
L R_{n}^{*}(\gamma)=L R_{n}(\gamma) / \hat{\eta}^{2}=S_{n}(\gamma)-S_{n}(\hat{\gamma}) / \hat{\sigma}^{2} \hat{\eta}^{2}
$$

And an amended confidence region

$\hat{\Gamma}^{*}=\left\{\gamma: L R_{n}(\gamma) \leq c\right\}$

These confidence intervals are asymptotically correct under the assumption that $\delta_{n} \rightarrow 0$ as $n \rightarrow \infty$, which suggests that the actual coverage may differ from the desired level for large values of $\delta_{n}$, consequently letting $\underline{\hat{\theta}}=\left(\theta, \delta_{n}\right)$ and $\underline{\hat{\theta}}=\left(\hat{\theta}, \hat{\delta}_{n}\right)$. From the derivation of Hansen $(2000)$,

$$
\sqrt{n}(\underline{\hat{\theta}}-\underline{\theta}) \rightarrow_{d} Z \mathrm{Z} 0, \mathrm{Y}
$$

Where $V_{\theta}$ is the standard asymptotic covariance matrix if $\gamma=\gamma_{0}$ when fixed. This means that we can approximate the distribution of $\underline{\hat{\theta}}$ by the conventional normal approximation as if $\gamma$ were know with certainty.

\section{Empirical Results and Analysis}

\subsection{Data Description}

For our investigation, we used Taiwan's publicly-listed firms as of December 31, 1998 as our sample. Our sample period runs from 1998 to 2013. We excluded banks, insurance companies and utilities because of the difficulty in calculating R\&D expenditures for banks and because government regulation is different from that of other industries. We select companies with financial statements, year-end and complete data, eliminating companies with incomplete data. The data are derived from the Taiwan Economic Journal (TEJ) Database. The database contains financial statements, individual stock, and ownership structure information, which helped to measure key variables for our objectives. These variables include stock price, employee number, R\&D expenditures, M/B ratio, long-term debt, total assets, ROA, operating cash flow. After computing and eliminating incomplete data, the final sample consists of 469 firms and 4221 observations from 1998 to 2013. These data form balanced panel data.

\subsection{Statistics and Data Analysis}

Table 1 presents descriptive information for our sample of firms. This table provides means, standard deviation, minimum, maximum, 25th percentile and 75th percentile value for the main variable in our sample. The statistics in the table shows that the mean of EDF is 0.0075 ; the minimum and maximum is 0 and 1 . This implies that the default probability of a company is quite distinct. The mean and standard deviation of EVHC is -0.0652 and 1.4226 , respectively; the phenomenon may show that firms generally are indifferent to the invisible effect on future performance. The 25 th percentile and 75 th percentile is -1.0878 and 0.8437 , respectively, suggesting that the policy of human resources inputs is diverse. The M/B Ratio, our measure of market performance, has a mean value of 1.4666 with a maximum and minimum value of 25.8077 and 0.0979 , respectively. RADR is the R\&D expenditure divided by total assets; the mean 25th percentile and 75th percentile are 0.0010 and 0.0275 , respectively. The result likely indicates two different reasons: one is because of a different industry classification, and the other is that many firms still despise research influence. OCFR represents the amount of cash generated by a firm's normal business operation; the mean and standard deviation are 0.0836 and 0.0912 , respectively, in our sample. These results also show divergence on cash flow. 
Table 1. Descriptive statisitic

\begin{tabular}{|c|c|c|c|c|c|c|}
\hline & Mean & Standard deviation & Min & Max & 25th percentile & 75th percentile \\
\hline EDF & 0.0075 & 0.0680 & 0.0000 & 1.0000 & 0.0000 & 0.0000 \\
\hline EVHC & -0.0652 & 1.4226 & -3.7400 & 4.7670 & -1.0878 & 0.8437 \\
\hline M/B Ratio & 1.4666 & 1.2072 & 0.0979 & 25.8077 & 0.7997 & 1.7501 \\
\hline LD & 0.0721 & 0.0907 & 0.0000 & 0.7091 & 0.0000 & 0.1199 \\
\hline RADR & 0.0216 & 0.0346 & 0.0000 & 0.3777 & 0.0010 & 0.0275 \\
\hline SIZE & 15.5523 & 1.4624 & 10.3557 & 20.9567 & 14.5626 & 16.3354 \\
\hline OCFR & 0.0836 & 0.0912 & 0.0000 & 1.5692 & 0.0136 & 0.1251 \\
\hline
\end{tabular}

Note. EDF represents the expected default frequency. EVHC is a firm's excess value of human capital. The M/B Ratio is the ratio of market value to book value of equity. LD is defined as long-term debt divided by the book value of total assets. RADR is a firm's research and development expenditures divided by the total asset ratio. Size is defined as the natural logarithm of total assets. OCFR represents the operating cash flow.

\subsection{Pooled Regression Results}

Our main interest is the relation among human resources, firm performance and enterprise risk. We explore this relation by two means that examine whether threshold effects exist. If there is a threshold effect on the relation, this effect suggests the existence of a non-linear relation. We first use pooled regression to analyze EDF and other variables. Second, given that a non-linear relation exists, we will further examine the threshold effect. Table 2 presents pooled regression results. In pooled regression results, the EVHC has a negative and significant effect at the $1 \%$ level. According to Pantzalis and Park (2009) and to initial inference, enterprise risk is decreased by more human resources inputs that imply shortage. Assuming the market is efficient and the stock price reflects all relevant information, a company should increase its human resources budget for maximum efficiency. Another reason is that EVHC as a risk measure will be a prediction of future risk. EVHC, price-to-earning and price-to-book are used similarly, of or relating to return or future growth. The other reason is that most firms do not disclose all relevant information on intangibles. If a company reports its entire body of intangible information, investors will have strong confidence, reducing the impact on stock price. LD is significantly positive at 5\% significance; more risk is reasonable compared with the lower company debt. In addition, the size is significant: -4.0438 for default risk at the $1 \%$ significance level. All firms have a distinct credit rating reflecting their debt-paying ability. Generally, large companies own more total assets as collateral to pay debt. EDF is the default risk for the following year; the large size of firms reduces their risk in normal situations.

Table 2. Empirical results from the pooled regression model without threshold effect

\begin{tabular}{lcc}
\hline & Coefficient & $t$-Stat. \\
\hline Constant & 0.0658 & $4.3370^{* * *}$ \\
EVHC & -0.0043 & $-4.1287^{* * *}$ \\
M/B Ratio & 0.0018 & 0.8354 \\
LD & 0.0576 & $2.2054^{* *}$ \\
RADR & 0.0089 & 0.3165 \\
SIZE & -0.0043 & $-4.0438^{* * *}$ \\
OCFR & 0.0215 & 0.6084 \\
\hline Sum of Squared Errors & 19.1540 & \\
R-squared & 0.0170 & \\
Observations & 4221 & \\
\hline
\end{tabular}

Note. $* * *, * *, *$ corresponds to significance at the $1 \%, 5 \%$, and $10 \%$ levels, respectively.

\subsection{Threshold Effect}

The results from the prior section suggest that size exhibits a negative effect on risk. In Taiwan, over $90 \%$ of firms are small and medium enterprises. Most firms are family controlled; prior papers indicated that family-owned businesses have the characteristic of weak corporate governance (Fan \& Wong, 2002; Leuz, Nanda, \& Wysocki, 2003). Size could be a key threshold variable. In this section, we further examine nonlinearities between size and risk. In table 3, the results of a single threshold effect between size and risk on a $1 \%$ significant level are shown. Using the single threshold model, we divide total observations into two regimes. 
When $\mathrm{q}>13.5028$, the observations could be defined as a large size regime; when $\mathrm{q} \leq 13.5028$, the observations could be defined as a small size regime. In addition, the multiple threshold variables are also considered in our examination. Table 3 shows that the bootstrap p-value of a small size regime is insignificant with 0.3467 . No second threshold effect exists while the size is under 13.5824. Furthermore, our sample exhibits heteroskedasticity, which implies different characteristics in each company. Table 3 also documents the result from the tests for the threshold effect and corresponds to a 95\% confidence interval.

Table 3. Tests for the threshold effect: P-value from LR tests and threshold estimates [95\% confidence interval]

\begin{tabular}{lccc}
\hline & Single threshold variable & Multiple threshold variables \\
\hline Threshold variable & Size & M/B(over size 13.5824) & M/B(under size 13.5824) \\
LR-test & 32.0834 & 25.0511 & 12.5057 \\
\hline Bootstrap p-value & 0.0000 & 0.0000 & 0.3467 \\
\hline Heteroskedasticity test p-value & 0.0000 & 0.0000 & 0.3780 \\
\hline & Threshold estimates and $[95 \%$ confidence interval] & M/B (under size 13.5824) \\
\hline Threshold variable & Size & M/B(over size 13.5824) & 2.5699 \\
q & $13.5028^{* * *}$ & $0.3108 * * *$ & {$[2.2933,4.9171]$} \\
\hline $95 \%$ confidence interval & {$[13.5027,13.5466]$} & {$[0.2172,0.4472]$} &
\end{tabular}

Note. M/B Ratio is the ratio of market value to book value of equity. Size is defined as natural logarithm of total assets.

Table 4 represents the result of the threshold model for the first threshold variable. In a large size regime, EVHC is significant with -0.0031 at the $1 \%$ significance level. A large company may own more advantageous resources to enhance the development of human capital. Carpenter et al. (2001) also agree regarding the competition of large firms, which is based on unique experience and resources. The long coefficient of debt is significant with 0.0470 for risk at the $5 \%$ significance level; thus, it is natural for firms to increase risk.

Table 4. Threshold model for the single threshold variable

\begin{tabular}{lcc}
\hline & Large Size Regime & Small Size Regime \\
\hline & Regime 1 & Regime 2 \\
(t-Stat.) & (-Stat.) \\
\hline \multirow{2}{*}{ Eonstant } & $0.0269^{* * *}$ & -0.6515 \\
& $(2.5070)$ & $(0.1955)$ \\
& $-0.0031^{* * *}$ & -0.0395 \\
M/B Ratio & $(-3.3650)$ & $(-0.3166)$ \\
& 0.0002 & 0.0223 \\
LD & $(0.1167)$ & $(0.1349)$ \\
& $0.0470^{* *}$ & 0.0259 \\
RADR & $(1.8309)$ & $(0.5126)$ \\
& 0.0139 & -0.1380 \\
SIZE & $(0.7108)$ & $(0.0822)$ \\
& $-0.0016^{* *}$ & 0.0506 \\
OCFR & $(-2.2498)$ & $(-0.1699)$ \\
& -0.0037 & 0.1782 \\
Sum of Squared Errors & $(-0.2409)$ & $(0.1440)$ \\
R-squared & 11.4524 & 6.7601 \\
Observations & 0.0137 & 0.1040 \\
\hline
\end{tabular}

Note. $* * *, * * *$ corresponds to significance at $1 \%, 5 \%$, and $10 \%$ levels, respectively. 


\subsection{The Threshold Variable of the M/B Ratio in Multiple Regimes}

In the previous section, this paper finds that human resources is significant and has a negative effect on risk in a large size regime. We aimed to explore the effect on well or poorly performing companies, further classified into two subsidiary sets by choosing the M/B Ratio as a second threshold variable. In our study, the M/B ratio does not solely represent firm performance but is also a proxy of a firm's future growth opportunity. Table 5 represents the Threshold estimated for single threshold varilable and multiple threshold varilables. Given the relevant of non-linear relationship between human resources and enterprise risk, the effects of both size and M/B ratio are simultaneously examined in our sample. The results show that when size is greater than 13.5824 , we divide into regime 3 and regime 4 as an M/B Ratio $>0.3108$ and an M/B Ratio $\leq 0.3108$, respectively.

Table 5. Threshold estimation for single threshold varilable and multiple threshold varilables

\begin{tabular}{cccc}
\hline & $\begin{array}{c}\text { Single threshold estimation } \\
(\mathrm{q}=\text { Size })\end{array}$ & \multicolumn{2}{c}{$\begin{array}{c}\text { Multiple threshold estimation } \\
(\mathrm{q} 1=\text { Size, q2=M/B Ratio })\end{array}$} \\
\hline \multirow{3}{*}{ Threshold variable } & Regime 1: Size>13.5028 & $\begin{array}{c}\text { Regime 3: Size }>13.5824 \\
\text { Regime 4: Size }>13.5824\end{array}$ & $\begin{array}{c}\text { M/B Ratio }>0.3108 \\
\text { M/B Ratio } \leq 0.3108\end{array}$ \\
\cline { 2 - 4 } & Regime 2: Size $\leq 13.5028$ & - & - \\
\hline
\end{tabular}

Note. M/B Ratio is the ratio of market value to book value of equity. Size is defined as natural logarithm of total assets.

Table 6 also presents the results from threshold model of the multiple threshold variables. The second threshold variable is the M/B ratio, which represents the firm's performance and growth opportunity in two regimes. In particular, our objective is to investigate the relation among risk, human resources and firm performance. The classification clearly reveal whether human resources is significant. The regime 3 shows that EVHC is significantly negative at $5 \%$ significance. This implies that a large firm with high growth may be enhanced by a new level of efficiency with more human resources inputs. Additional human resources will help companies obtain more benefits and reduce risk. Regarding human resources's insignificance in large and poorly performing firms, human resources inputs should depend on the financial situation. LD is worth noticing; it is 0.0364 at a 5\% significance in large size and well-performing firms. These firms should increase debt depending on the business situation because large firms usually experience limitations on development and excess cash holding. Refinancing long-term debt would not help a firm to increase return and decrease risk. RADR is positive and significant in large firms with strong performance; increased R\&D expenditures likely increase risk. To source innovation ideas, companies occasionally choose to pursue equity investments (Dushnitsky \& Lenox, 2005). Philips and Zhdanov (2013) indicated that small firms can invest in R\&D to create innovation, and sell the innovation to a large firm. Large firms should merge with small firms to increase the patent demand. This leads to an interesting inference: a large firm with a high $\mathrm{M} / \mathrm{B}$ ratio should focus on merging with company owning useful patents. Deciding to increase R\&D expenditures may not increase a company's profitability and competitiveness. Size has negative significance with risk; large firms usually own more resources to take on risk. In comparison, althought the estimation from the firms with large size and low growth does not present statisitical significantly outcomes, OCFR has a negative significance with risk in regime 3. In general, operation cash flow implies the quantity of cash generated by a firm's normal business operation. Therefore, a firm may generate a high cash flow that contributes two-fold. One is helpful to a firm's debt-payment ability; the other is helpful in increasing cash holdings to invest in potential projects. It is relatively rare that companies lacking cash flow can make investments. However, it is possible that the more operating cash flow may increase the agency problem if the firm has no well investment project in future. Therefore, the opposite relationship between OCFR and risk in regime 3 also suggests that a firm should estiablish well corporate governance mechanism to mitigate the potential agency problem. 
Table 6. Threshold model for the multiple threshold variables

\begin{tabular}{ccc}
\hline Variables & $\begin{array}{c}\text { Regime } 3 \\
(t \text {-Stat. })\end{array}$ & $\begin{array}{c}\text { Regime } 4 \\
(t \text {-Stat. })\end{array}$ \\
\hline \multirow{2}{*}{ Constant } & $0.0160^{*}$ & 1.6193 \\
& $(1.6138)$ & $(0.0395)$ \\
EVHC & $-0.0016^{* *}$ & -0.0196 \\
& $(-2.2924)$ & $(-0.0923)$ \\
M/B Ratio & 0.0011 & -0.2602 \\
LD & $(0.6352)$ & $(0.0002)$ \\
& $0.0364^{* *}$ & 1.1618 \\
RADR & $(1.7150)$ & $(0.0750)$ \\
& $0.0211^{*}$ & 1.5968 \\
SIZE & $(1.2617)$ & $(0.0037)$ \\
& $-0.0010^{*}$ & -0.1023 \\
OCFR & $(-1.5314)$ & $(-0.0378)$ \\
& $-0.0134^{*}$ & 1.3364 \\
R-squared & $(-1.3445)$ & $(-0.0035)$ \\
\hline Observations & 6.5062 & 2.8812 \\
\end{tabular}

Note. $* * * * *, *$ corresponds to significance at $1 \%, 5 \%$, and $10 \%$ levels, respectively.

\section{Conclusion}

Our study's purpose is to investigate the relation among intangible assets, firm performance and enterprise risk in Taiwan-listed companies. Pantzalis and Park (2009) propose the excess value of human capital concept (EVHC); we further use EVHC to analyze the asysmetric effect on risk. In the data collection process, the data form exhibits the heteroskedasticity phenomenon, which implies different characteristics in each company. Therefore, this paper uses panel data to solve the problem of heteroskedasticity. Empirical results show that EVHC, the M/B ratio and size significantly influence the risk. Similar to prior studies, size could be a key variable to divide into two sub-samples. The multiple regimes model proposed by Hansen (2000) had been adopted to examine the threshold effect on risk. Therefore, we chose firm size as the threshold variable. The results show that the threshold effect of size on riks exists. In large firms, the EVHC is negative and significant because of the advantage of increased resources. Over the long-term debt is significantly positive. Thus, it is natural for a firm to increase risk. To analyze the phenomenon, this paper also examined the effect on well and poorly performing companies. The M/B ratio provides a suitable proxy for a firm's growth opportunity.

Under a large size regime, there exists two regimes of high and low M/B ratios. From the high M/B ratio regime results, the EVHC is also negative and significant. This finding suggests that large, well-performing firms may be enhanced by a new level of efficiency with more human resources inputs. More human resources will help companies obtain increased benefits and reduce risk. In addition, our results show that a large firm with a high growth must increase its cash flow stability, to ease company debt repayment pressures and to establish a good corporate governance mechanism. Finally, considering the cross-country difference, we also suggest that future research could select a different country and industry to examine the relationships between human resource input and enterprise risk.

\section{References}

Acharya, V., Davydenko, S. A., \& Strebulaev, L. A. (2012). Cash holding and credit risk. Review of Financial Studies, 25, 3572-3609. http://dx.doi.org/10.1093/rfs/hhs106

Attar, A. A., Hussain S., \& Zuo, L. Y. (2008). Earning equity, bankruptcy risk and future cash flows. Accounting and Businesses Research, 38, 5-20. http://dx.doi.org/10.1080/00014788.2008.9663317

Baker, M., \& Wurglar, J. (2002). Market timing and capital structure. Journal of Finance, 57, 1-32. http://dx.doi.org/10.1111/1540-6261.00414 
Ballot, G., Fakhfakh, F., \& Taymaz, E. (2001). Firm's human capital, R\&D and performance: A study on French and Swedish Firms. Labour Economics, 8, 443-462. http://dx.doi.org/10.1016/S0927-5371(01)00038-0

Batt, R. (2000). Managing customer services: human resources practices, quit rates, and sales growth. Academy of Management Journal, 45, 587-597. http://dx.doi.org/10.2307/3069383

Bhattacharya, P. K., \& Brockwell, P. J. (1976). The minimum of an additive process with applications to signal estimation and storage theory. Probability Theory and Related Fields, 37, 51-75. http://dx.doi.org/10.1007/bf00536298

Bloom, N., \& Reene, J. V. (2002). Patents, real options, and firm performance. Economic Journal, 112, 97-116. http://dx.doi.org/10.1111/1468-0297.00022

Bosma, N., Praag, M. V., Thurik, R., \& Wit, G. D. (2004). The value of human and social capital investment for the business performance of startups. Small Business Economics, 23, 227-236. http://dx.doi.org/10.1023/B:SBEJ.0000032032.21192.72

Brown, J. R., Fazzari, S. M., \& Petersen, B. C. (2009). Financing innovation and growth: Cash flow, external equity, and the 1990s R\&D boom. Journal of Finance, 64, 151-185. http://dx.doi.org/10.1111/j.1540-6261.2008.01431.x

Brush, T. H., Bromiley, P., \& Hendrickx, M. (2000). The free cash flow hypothesis for sales growth and firm $\begin{array}{lllll}\text { performance. } & \text { Strategic } & \text { Management } & \text { Journal, } & 21,\end{array}$ http://dx.doi.org/10.1002/(SICI)1097-0266(200004)21:4<455::AID-SMJ83>3.0.CO;2-P

Carpenter, M. A., Sanders, W. G., \& Gregersen, H. B. (2001). Bunding human capital with organization context: The impact of international assignment experience on multinational firm performance and CEO pay. Academy of Management Journal, 44, 493-511. http://dx.doi.org/10.2307/3069366

Cheng, M. Y., Lin, J. Y., Hsiao, T. Y., \& Lin, T. W. (2010). Invested resource, competitive intellectual capital, and corporate performance. Journal of Intellectual Capital, 11, 433-450. http://dx.doi.org/10.1108/14691931011085623

Coad, A. \& Rao, R. (2010). Firm growth and R\&D expenditure. Economic of Innovation and New Technology, 19, 127-145. http://dx.doi.org/10.1080/10438590802472531

Coff, R. W. (2002). Human capital, shared expertise, and the likelihood of impasse in corporate acquisitions. Journal of Management, 28, 107-128. http://dx.doi.org/10.1177/014920630202800107

Delios, A., \& Beamish, P. W. (2001). Survival and profitability: The Roles of experience and intangible assets in foreign subsidiary performance. Academy of Management Journal, 44, 1028-1038. http://dx.doi.org/10.2307/3069446

Duffie, D., \& Pan, J. (1997). An overview of value at risk. Journal of Derivatives, 4, 7-49. http://dx.doi.org/10.3905/jod.1997.407971

Dufour, J. M. (1997). Some impossibility theorems in econometrics with applications to structural and dynamic models. Econometrica, 65, 1365-1387. http://dx.doi.org/10.2307/2171740

Dushnitsky, G., \& Lenox, M. J. (2005). When do firms undertake R\&D by investing in new ventures? Strategic Management Journal, 26, 947-965. http://dx.doi.org/10.1002/smj.488

Estrada, J. (2001). Systematic risk in emerging market: the D-CAPM. Emerging Markets Quarterly, 3, 365-379. http://dx.doi.org/10.1016/S1566-0141(02)00042-0

Fan, J. P. H., \& Wong, T. J. (2002). Corporate ownership structure and the informativeness of accounting earnings in East Asia. Journal of Accounting and Economics, 33, 401-425. http://dx.doi.org/10.1016/S0165-4101(02)00047-2

Gimeno, J., Folta, T. B., Cooper, A. C., \& Woo, C. Y. (1997). Survival of fittest? Entrepreneurial human capital and the persistence of underperformance firms. Administrative Science Quarterly, 42, 750-783. http://dx.doi.org/10.2307/2393656

Goh, P. C. (2005). Intellectual capital performance of commercial banks in Malaysian. Journal of Intellectual Capital, 6, 385-396. http://dx.doi.org/10.1108/14691930510611120

Guest, D. E. (2010). Human resources management and performance: still searching for some answers. Human Resources Management Journal, 21, 3-13. http://dx.doi.org/10.1111/j.1748-8583.2010.00164.x

Hansen, B. E. (1999). Threshold effects in Non-Dynamic panels: Estimation, testing, and inference. Journal of 
Econometrics, 93, 345-368. http://dx.doi.org/10.1016/S0304-4076(99)00025-1

Hansen, B. E. (2000). Sample splitting and threshold estimation. Econometrica, 68, 575-603. http://dx.doi.org/10.1111/1468-0262.00124

Haw, I. M., Qi, D., \& Wu, W. (2001). The nature of information in accruals and cash flows in an emerging capital market: The case of china. International Journal of Accounting, 36, 391-406. http://dx.doi.org/10.1016/S0020-7063(01)00107-8

Hayton, J. C. (2003). Strategic human capital management in SMEs: An empirical study of entrepreneurial performance. Human resources Management, 42, 375-391. http://dx.doi.org/10.1002/hrm.10096

Hirshleifer, D. (2001). Investor psychology and asset pricing. Journal of Finance, 56, 1533-1597. http://dx.doi.org/10.1111/0022-1082.00379

Hitt, M. A., Bierman, L., Shimizu, K., \& Kochhar, R. (2001). Direct and moderating effects of human capital on strategic and performance in professional service firms: A resource-based perspective. Academy of Management Journal, 44, 13-28. http://dx.doi.org/10.2307/3069334

Huselid, M. A., \& Becker, B. E. (2000). Comment on measurement error in research on human resources and firm performance: How much error is there and how does it influence effect size estimates? Personnel Psychology, 53, 835-854. http://dx.doi.org/10.1111/j.1744-6570.2000.tb02419.x

Huselid, M. A., Jackson, S. E., \& Schuler, R. S. (1997). Technical and strategic human resources management effectiveness as determinants of firm performance. Academy of Management Journal, 40, 171-188. http://dx.doi.org/10.2307/257025

Hoyt, R. E., \& Liebengberg, A. P. (2011). The value of enterprise risk management. Journal of Risk and Insurance, 78, 795-822. http://dx.doi.org/10.1111/j.1539-6975.2011.01413.x

Johnson, S., Boone, P., Breach, A., \& Friedman, E. (2000). Corporate governance in the Asia financial crisis. Journal of Financial Economics, 58, 141-186. http://dx.doi.org/10.1016/S0304-405X(00)00069-6

Kalcheva, I., \& Lins, K. V. (2007). International evidence on cash holding and expected managerial agency problems. Reviews of Financial Studies, 20, 1087-1112. http://dx.doi.org/10.1093/rfs/hhm023

Kang, K. H., Lee, S., Choi, K., \& Lee, K. (2012). Geographical diversification, risk and firm performance of US casinos. Tourism Geographies: An International Journal of Tourism Space, Place and Environment, 14, 117-146. http://dx.doi.org/10.1080/14616688.2011.593043

Kini, O., \& Williams, R. (2012). Tournament incentives, firm risk, and corporate policies. Journal of Financial Economics, 103, 350-376. http://dx.doi.org/10.1016/j.jfineco.2011.09.005

Lakonishok, J., \& Shapiro, A. C. (1986), System risk, total risk and size as determinants of stock market returns. Journal of Banking \& Finance, 10, 115-132. http://dx.doi.org/10.1016/0378-4266(86)90023-3

Lepak, D. P., \& Snell, S. A. (2002). Examining the human resources architecture: the relationships among human capital, employment, and human resources configurations. Journal of Management, 28, 517-543. http://dx.doi.org/10.1177/014920630202800403

Leuz, C., Nanda, D., \& Wysocki, P. D. (2003). Earnings management and investor protection: An international $\begin{array}{lllll}\text { comparison. Journal of Financial } & \text { Economics, } & 69, & 505-527 .\end{array}$ http://dx.doi.org/10.1016/S0304-405X(03)00121-1

Lev, B. (2001). Intangibles: Management, measurement, and reporting. Washington D.C.: Brooking Institution Press.

Liu, S. J., \& Shyu, J. (2004). Strategic planning for technology development with patent analysis. International Journal of Technology and Management, 13, 661-680. http://dx.doi.org/10.1504/IJTM.1997.001689

Lu, J. W., \& Beamish, P. W. (2004). International diversification and firm performance: the S-curve hypothesis. Academy of Management Journal, 47, 598-609. http://dx.doi.org/10.2307/20159604

Mavridis, D. G. (2004). The intellectual capital performance of the Japanese banking sector. Journal of Intellectual Capital, 5, 92-115. http://dx.doi.org/10.1108/14691930410512941

Mcshane, M. K., Nair, A., \& Rustambekov, E. (2011). Does enterprise risk management increase firm value? Journal of Accounting, 26, 641-658. http://dx.doi.org/10.1177/0148558x11409160

Naoki, S. (2012). Firm cash holding and performance: Evidence from Japanese corporate Finance, RIETI 
Discussion Paper Series. Development Bank of Japan, 12-E-031.

Oderda, G., Dacorogna, M. M. \& Jung, T. (2003). Credit risk model-do they deliver their promises? A Quantitative Assessment, Economic Notes, 32, 177-195. http://dx.doi.org/10.1111/1468-0300.00110

Pagach, D. P., \& Warr, R. S. (2010). The effect of enterprise risk management on firm performance. Social Science Research Network Working Paper. http://dx.doi.org/10.2139/ssrn.1155218

Palazzo, B. (2012). Cash holding, risk, and expected returns. Journal of Financial Economics, 104, 162-185. http://dx.doi.org/10.1016/j.jfineco.2011.12.009

Pantzalis, C., \& Park, J. C. (2009). Equity market valuation of human capital and stock teturns. Journal of Banking and Finance, 33, 1610-1623. http://dx.doi.org/10.1016/j.jbankfin.2009.03.008

Penman, S., \& Reggiani, F. (2013). Returns to buying earnings and book value: accounting for growth and risk, Reviews of Accounting Studies, 18, 1021-1049. http://dx.doi.org/10.1007/s11142-013-9226-y

Philips, G. M., \& Zhdanov, A. (2012). R\&D and the incentives from merger and acquisition activity. Review of Financial Studies, 26, 34-78. http://dx.doi.org/10.1093/rfs/hhs109

Podobnik, B., Horvatic, D., Petersen, A. M., \& Stanley, H. E. (2009). Quantitative relations between Risk, return and firm Size. Europhysics Letters, 85, 1-5. http://dx.doi.org/10.1209/0295-5075/85/50003

Psillaki, M., Tsolas L. E., \& Margaritis, D. (2010). Evaluation of credit risk based on firm performance. European Journal of Operational Research, 201, 873-881.

Quon, T. K., Zeghal, D., \& Maingot, M. (2012). Enterprise risk management and firm performance. World Conference on Business. Economics and Management, 62, 263-267.

Singla, C., Veliyath, R., \& George, R. (2014). Family firms and internationalization-governance relationships: Evidence of secondary agency issues. Strategic Management Journal, 35, 606-616. http://dx.doi.org/10.1002/smj.2111

Skaggs, B. C., \& Youndt, M. (2004). Strategic positioning, human capital, and performance in service organization performances: A Customer Interaction Approach. Strategic Management Journal, 25, 85-99. http://dx.doi.org/10.1002/smj.365

Sherer, P. D. (1995). Leverage human assets in law firms: Human capital structures and organizational capabilities. Industrial and Labor Relations Review, 48, 671-691. http://dx.doi.org/10.1177/001979399504800405

Shrader, R., \& Siegel, D. S. (2007). Assessing the relationship between human capital and firm performance: Evidence from technology-based new ventures. Entrepreneurship Theory and Practice, 31, 893-908. http://dx.doi.org/10.1111/j.1540-6520.2007.00206.x

Soininen, J., Martikainen, M., Puumalainen, K., \& Kylaheiko, K. (2012). Entrepreneurial orientation: Growth and profitability of finish small-and medium-sized enterprises. International Journal of Production Economics, 140, 614-621. http://dx.doi.org/10.1016/j.ijpe.2011.05.029

Tubbs, M. (2007). The relationship between R\&D and company performance. Research-Technology Management, 50, 23-30.

Vassalou, M., \& Xing, Y. (2004). Default risk in equity returns. Journal of Finance, 59, 831-868. http://dx.doi.org/10.1111/j.1540-6261.2004.00650.x

Wu, S. H., \& Hsu, F. B. (2001). Towards a knowledge-based view of OEM relationship building: Sharing of industrial experiences in Taiwan. International Journal of Technology Management, 22, 503-524.

Youndt, M. A., \& Snell, S. A. (2004). Human resources configuration, intellectual capital, and organizational performance. Journal of Managerial Issues, 16, 337-360.

Zeghal, D., \& Maaloul, A. (2010). Analysing value added as an indicator of intellectual capital and its consequences on company performance. Journal of Intellectual Capital, 11, 39-60. http://dx.doi.org/10.1108/14691931011013325

\section{Note}

Note 1. For a detailed discussion on the asymptotic distribution, see Hansen (2000). 


\section{Copyrights}

Copyright for this article is retained by the author(s), with first publication rights granted to the journal.

This is an open-access article distributed under the terms and conditions of the Creative Commons Attribution license (http://creativecommons.org/licenses/by/3.0/). 